\title{
PERBEDAAN EFEK LATIHAN MEDICINE BALL DAN CLAPPING PUSH UP TERHADAP DAYA LEDAK OTOT LENGAN PEMAIN BULUTANGKIS REMAJA USIA 13 - 16 TAHUN
}

\author{
Nurul Fithriati Haritsa, Bambang Trisnowiyanto \\ Poltekes Negeri Surakarta. Jl. Kapten Adisumarmo Tohudan Colomadu Karanganyar \\ Surakarta 57173
}

\begin{abstract}
Abstrak. Penelitian ini adalah penelitian eksperimental lapangan dengan rancangan penelitian yang digunakan adalah two group pre test - post test design yang bertujuan untuk mengetahui pengaruh latihan medicine ball dan clapping push up terhadap daya ledak otot lengan pemain bulutangkis remaja usia 13 - 16 tahun berjumlah 36 orang laki-laki dikelompokkan secara acak menjadi 2 kelompok yaitu kelompok K1 sebagai kelompok latihan medicine ball dan K2 kelompok latihan clapping push up. Perlakuan pada penelitian ini adalah latihan medicine ball dengan intensitas 70-80\%, 2-3 set, 8-15 repetisi, istirahat tiap set 2 menit dan latihan clapping push up 2-3 set, 8-12 repetisi, istirahat tiap set 2 menit yang dilakukan selama 6 minggu. Yang menjadi variabel dalam penelitian ini adalah latihan medicine ball, latihan clapping push up dan daya ledak otot lengan. Hasil yang didapat pada daya ledak otot lengan sebelum latihan pada kelompok medicine ball (K1) $(5,727 \pm 0,956$ meter) dan kelompok clapping push up (K2) $(5,155 \pm 1,137)$. Rata-rata daya ledak otot lengan setelah latihan pada kelompok medicine ball (K1) $(7,183 \pm 0,937)$ dan kelompok clapping push up (K2) $(5,944 \pm 1,121)$. Hasil dari penelitian ini latihan medicine ball dapat meningkatkan daya ledak otot lengan, latihan clapping push up dapat meningkatkan daya ledak otot lengan, latihan medicine ball lebih meningkatkan daya ledak otot lengan pemain bulutangkis remaja usia 13 - 16 tahun dibandingkan latihan clapping push up.
\end{abstract}

Kata kunci: latihan medicine ball, latihan clapping push up, daya ledak otot lengan

\begin{abstract}
This research was a field-experimental research with two-group pretest posttest design that aimed to determine the effect of medicine ball training and clapping push-ups against arm muscle explosive power in 36 adolescents aged 13-16 year-old badminton players then were randomly divided into 2 groups: $K 1$ and $K 2$ groups. K1 goup received medicine ball exercise; with the intensity of 70-80\%, 2-3 sets, 8-15 reps, rest 2 minutes each set, while K2 group received clapping push-ups exercise; 2-3 sets, 8-12 reps, rest each set of 2 minutes conducted over 6 weeks. The results obtained on arm muscle explosive power before exercise in medicine ball (K1) group was $5.727 \pm 0.956$ meters and in clapping push-ups (K2) group was $5.155 \pm$ 1.137. An average arm muscle explosive power after exercise in K1 group was $7.183 \pm 0.937$ and in K2 group was 5,944 $\pm 1,121$. The conclusions were medicine ball exercises could increase arm muscle explosive power 13-16 year-old badminton players, clapping push-ups training could increase arm muscle explosive power in 13-16 year-old badminton players, and medicine
\end{abstract}




\section{ball exercise could increase arm muscle explosive power higher than clapping}

push up practice in 13-16 year-old badminton players.

Keywords: medicine ball exercise, clapping push-up exercise, arm muscle explosive power

\section{PENDAHULUAN}

Bulutangkis merupakan salah satu cabang olahraga yang saat ini populer di dunia dan banyak menarik minat berbagai kelompok umur khususnya di Indonesia. Olahraga bulutangkis menjadikan Indonesia berkembang menjadi negara yang maju di dunia olahraga. Proses berkembangnya olahraga bulutangkis dan PBSI menumbuhkan rasa nasionalisme tersendiri di dalam olahraga (Icuk, 2002).

Masa pubertas adalah fase yang penting untuk mengembangkan unsur kekuatan dan kecepatan, fase ini bukanlah suatu fase krisis seperti yang dipercaya pada waktu lalu. Segala latihan seharusnya dilatihkan, mulai dari latihan kekuatan dan kecepatan tubuh bagian atas sampai dengan latihan kaki. Latihan daya ledak yang adequat adalah hal yang penting, terutama latihan daya ledak otot lengan yang berkontribusi terhadap pukulan smash permainan bulutangkis (Komi, 1992).

Penampilan fisik pada anak-anak dan adolescence selalu dinilai dari sudut pandang proses pertumbuhannya. Pertumbuhan meliputi rangkaian tahap pertumbuhan yang sama pada setiap orang, sedangkan perbedaannya secara individual adalah pada faktor keturunan, diet, latihan atau kegiatan dan kesehatan yang memungkinkan mempengaruhi tahap-tahap tersebut sampai keadaan atau tingkat tertentu, tetapi pola dasarnya tetap sama (Brooks\&Fahey, 1985: 661).

Clapping push up merupakan latihan pliometrik dengan menggunakan beban tubuh sendiri untuk meningkatkan kekuatan otototot lengan (Chu, 1996). Selama ini latihan clapping push up dijadikan dasar latihan untuk meningkatkan daya ledak otot lengan remaja pada permainan bulutangkis. Sebagian ahli berpendapat bahwa latihan clapping push up menimbulkan efek negatif seperti terjadinya kerusakan epiphysis, pertumbuhan tulang dan tulang panjang (Avery, dkk).

Medicine ball merupakan salah satu bentuk latihan pliometrik dengan menggunakan alat semacam bola untuk meningkatkan power dan kekuatan otot lengan. Latihan pliometrik merupakan suatu metode untuk mengembangkan explosive power. Power atau daya ledak ialah kombinasi dari kecepatan maksimal dan kekuatan maksimal. Keunggulan latihan pliometrik adalah kontraksi yang sangat kuat merupakan respon dari pembebanan regangan dinamik dari otot-otot yang terlibat. Regangan yang terjadi secara mendadak sebelum otot kembali berkontraksi memungkinkan otototot mencapai kekuatan maksimal dalam waktu yang singkat (Radcliffe dan Farantinos, 2002). Latihan medicine ball dapat dijadikan alternatif latihan, sebagai pengganti clapping push up dalam meningkatkan daya ledak otot lengan. Radcliffe (1985) mengemukakan bahwa latihan medicine ball memberikan arti bagi gerak power tubuh secara lengkap dan dapat diaplikasikan dalam olahraga bulutangkis, angkat besi dan gulat.

Latihan fisik yang baik dan sistematis akan memberikan manfaat bagi sistem organ tubuh manusia, antara lain adalah manfaat pada aspek sistem syaraf pusat, meningkatnya konduksi impuls saraf, mempercepat waktu gerak dan waktu reaksi, meningkatkan kekuatan dan kecepatan maksimal, meningkatkan fungsi serabut otot, meningkatkan sintesa protein untuk pengembangan otot, serta bertambahnya massa otot (Zumerchik, 1997: 593).

Kedua bentuk latihan clapping push up dan medicine ball di atas sama-sama sebagai bentuk latihan explosive power, sedangkan perbedaan kedua latihan ini belum diketahui. 
Berdasarkan latar belakang masalah, maka peneliti mencoba menguji perbedaan efek latihan medicine ball dan clapping push up dalam meningkatkan daya ledak otot lengan pemain bulutangkis remaja usia 13-16 tahun.

\section{MATERI}

\section{Olahraga Bulutangkis}

Bulutangkis adalah cabang olahraga yang termasuk ke dalam kelompok olahraga permainan. Bulutangkis dimainkan di dalam maupun luar lapangan, di atas lapangan yang dibatasi dengan garis-garis dalam ukuran panjang dan lebar tertentu. Alat yang digunakan adalah raket, shuttlecock, dan lapangan.

Tujuan permainan bulutangkis adalah berusaha untuk menjatuhkan shuttlecock di daerah permainan lawan dan menjaga agar tidak jatuh di lapangan sendiri. Kekhasan permainan bulutangkis adalah pada objek permainan yang digunakan berupa shuttlecock yang dipukul bolak-balik (rally) menggunakan raket tanpa menyentuh lantai lapangan. Permainan bulutangkis tidak bisa lengkap bila tidak mengetahui dan memahami mengenai peraturan dan teknik permainannya secara langsung. Pola permainan bulutangkis tidak hanya mengarah pada segi keterampilan, berorientasi pada kematangan teknik pemain saja melainkan juga mengarah pada pola permainan yang cepat dan mengandalkan kelincahan yang tentunya perlu ditunjang dengan kemampuan fisik dan kesegaran jasmani yang baik pada atlet.

\section{Kontraksi otot}

Peristiwa mekanikan dan kimia kontraksi otot di bawah teori sliding filamen, dapat dibagi ke dalam lima fase yaitu: (1) fase istirahat, (2) fase excitation coupling, (3) fase kontraksi, (4) fase pengisian kembali dan (5) fase rileksasi (Fox, 1993: 101-102).

Di bawah kondisi istirahat, jembatan penyebrangan (cross bridge) dari filamen miosin menjulur kearah filamen aktin, tetapi tidak berhubungan. Suatu molekul ATP terikat pada ujung jembatan penyebrangan (ATP cross-bridge complex). Tidak adanya $\mathrm{Ca}++$, troponin dari filamen aktin menghambat jembatan penyebrangan miosin dari ikatan dengan aktin.

Impuls dari syaraf motor mencapai motor end plate, maka akan mensekresi neurotransmitter asetilkolin ke celah sinapyang berfungsi untuk mentransfer impuls saraf ke serat otot, yang selanjutnya berikatan dengan reseptor - reseptor pada sarkolema. Perintah elektrik tersebut selanjutnya ditransmisikan keseluruh panjang serat otot, dan dipercepat penyebarannya melalui T-tubules. Dlam perjalanannya, mereka memicu pelepasan $\mathrm{Ca}++$ dari sisterna, dan dengan segera terikat oleh molekul troponin $\mathrm{C}$ pada filamen aktin. Hasilnya, bagian aktif (active side) dari filamen aktin akan terbuka, sehingga kompleks ATP cross bridge menyerbu dan menempel pada bagian aktif filamen aktin (terbentuk kompleks aktomiosin) dan memungkinkan terjadinya kontraksi.

Ketika inervasi impuls dari saraf motor berhenti, $\mathrm{Ca}++$ terlepas dari troponin $\mathrm{C}$ dan secara aktif dipompa (calcium pump) kembali kedalam sisterna dari retikulum sarkoplasma. Masuknya $\mathrm{Ca}++$ kembali kedalam sisterna, bagian aktif dari filamen aktin tertutup kembali oleh tropomiosin. Hal ini menyebabkan terlepasnya kompleks ATP cross-bridge dari bagian aktif filamen aktin. Aktivitas ATPase dari miosin juga dihentikan dan tidak ada lagi pemecahan ATP. Mengakibatkan filamen otot kembali ke keadaan semula dan otot menjadi relax.

\section{Kumparan otot (Muscle spindle)}

Pada daerah reseptor kumparan otot terdapat dua macam ujung syaraf sensorik (aferen) yaitu: ujung primer (anulospiral), terdiri dari serat tipe Ia, yang dendritnya melingkari bagian tengah setiap serat intrafusal; dan ujung sekunder (race mosa / flower spray), yang termasuk dalam serat tipe II, yang mempersyarafi disalah satu ujung primer. 
Terdapat dua macam serat intrafusal yaitu: serat kantong nuklear (Nuclear Bag Intrafusal Fiber) yang hanya dipersyarafi oleh ujung syaraf primer, dan serat rantau nuklear (Nuclear Chain Intrafusal Fiber) yang dipersyarafi baik oleh ujung syaraf primer dan biasanya juga ujung syaraf sekunder. Serat rantai nuklear bertanggung jawab terhadap timbulnya respon statis, sedangkan serat kantong nuklear bertanggung jawab terhadap perubahan panjang yang secara tiba-tiba pada reseptor kumparan, yang selanjutnya merespon secara aktif dan ekstrem untuk menjalarkan banyak impuls menuju serat syaraf kemudian menuju medulla spinalis. Serat kantong nuklear bertanggung jawab terhadap kekuatan respon dinamik. Hal ini sangat berkaitan dengan pengaturan respon statik dan dinamik oleh syaraf motorik gamma, yang terbagi menjadi dua tipe yaitu: Gamma dinamik dan Gamma statik (Guyton dan Hall, 1996: 688). Jadi manifestasi yang paling sederhana dari fungsi kumparan otot (muscle spindle) adalah refleks regang otot yaitu kapanpun otot diregang maka eksitasi yang timbul pada kumparan akan menyebabkan refleks kontraksi serat otot rangka yang besar dari otot yang sama dan otot-otot sinerginya.

\section{Organ tendon golgi}

Organ tendon golgi berfungsi untuk mendeteksi tegangan otot serta melindungi tendon dan hubungan tendon - otot maupun hubungan tendon dengan tempat perlekatannya pada tulang (Guyton dan Hall. 1996: 691; Fox, 1993: 149).

Bila organ tendon golgi sebuah otot dirangsang oleh kenaikan tegangan otot, sinyalnya akan dijalarkan ke medula spinalis guna menimbulkan refleks yang akan mempengaruhi otot yang sesuai. Refleks ini seluruhnya bersifat menghambat. Refleks ini akan mencetuskan mekanisme umpan balik negatif yang nantinya akan mencegah agar tegangan pada otot tidak terlalu besar.

\section{Latihan fisik}

Harsono (1988 : 101) "training” adalah suatu proses yang sistematis dari berlatih atau bekerja yang dilakukan secara berulang-ulang, dengan menambah jumlah beban latihan tiap harinya. Menurut Bompa (1994: 4), latihan adalah upaya seseorang mempersiapkan dirinya untuk tujuan tertentu.

Bompa (1994: 5) menerangkan bahwa tujuan latihan adalah untuk memperbaiki prestasi tingkat terampil maupun kinerja atlet, dan diarahkan oleh pelatihnya untuk mencapai tujuan umum latihan. Sedangkan menurut Suharno (1981: 2) tujuan latihan adalah pembentukan atlet secara keseluruhan, meningkatkan kesegaran jasmani dinamis atlet, meningkatkan kesehatan, mencari kesenangan dan rekreasi, menyembuhkan penyakit, mengembangkan prestasi secara optimal.

\section{Latihan pliometrik}

Menurut Radcliffe \& Farentinos (1985: 3-7) bahwa latihan pliometrik adalah latihan yang memiliki ciri khusus yaitu kontraksi otot yang sangat kuat yang merupakan respon dari pembebanan dinamik atau regangan yang cepat dari otot-otot yang terlibat. Pliometrik disebut juga dengan reflek regang atau miotatik atau reflek muscle spindle. Pendapat lain dikemukakan oleh Fox, et al (1988:175) mengemukakan bahwa latihan pliometrik merupakan tipe bentuk program latihan kelima yang mengkombinasikan suatu regangan awal pada unit tendon yang diikuti oleh suatu kontraksi isotonik, sedangkan menurut Chu (1992:1-3) berpendapat bahwa latihan pliometrik adalah latihan yang memungkinkan otot untuk mencapai kekuatan maksimal dalam waktu yang sesingkat mungkin.

\section{Latihan medicine ball}

Latihan medicine ball dalam permainan bulutangkis khususnya passing atas merupakan suatu bentuk latihan yang terdiri dari rangkaian gerakan melempar bola medicine yang dimulai dari belakang kepala ke atas dan badan tegak, kedua tangan memegang bola dibelakang kepala dengan gerakan cepat bola di lemparkan ke depan. Medicine ball dalam penelitian ini dilakukan dengan posisi berdiri. Dari pendapat tentang pliometrik dengan 
pengertian medicine ball, dapat disimpulkan bahwa latihan pliometrik khususnya medicine ball adalah mengembangkan otot-otot lengan untuk mendapat rangsangan yang sama berupa berat bola medicine $2 \mathrm{~kg}$. Bentuk latihan ini merangsang berbagai perubahan pada otot dan meningkatkan kemampuan kelompok otot agar dapat merespon dengan cepat dan kuat (Ishak, 2012).

\section{Latihan clapping push up}

Clapping push up adalah salah satu bentuk latihan beban yang dilakukan dengan pembebanan berat badan dengan penambahan gerakan tepukan kedua telapak tangan ketika gerakan melayang atau melompat. Latihan push up digunakan untuk mengembangkan otot-otot pergelangan tangan dan tangan, otototot siku (tricep brachii dan anconeus), otototot shoulder (anterior deltoid) dan otot-otot dada (pectoralis mayor dan minor) (Arnheim, 1985 : Johnson, 1986, dan Luttgens, 1992) dalam Hermawan (1995: 37).

\section{METODE PENELITIAN}

Metode penelitian yang digunakan dalam penelitian ini adalah metode eksperimental lapangan dengan menggunakan rancangan randomized pre test and post test group design (Zainuddin, 2011). Populasi yang dipergunakan dalam penelitian ini adalah subjek dengan usia 13 - 16 tahun pada klub bulutangkis Pranata yang berjumlah 46 . Sampel penelitian diambil dari populasi yang mempunyai kriteria jenis kelamin laki-laki, mempunyai indeks masa tubuh normal, usia 13-16 tahun, berbadan sehat berdasarkan pemeriksaan dokter, bersedia menjadi subjek penelitian dari awal sampai penelitian selesai yang berjumlah 36 subjek. Sampel penelitian diambil dengan teknik simple random sampling, agar memenuhi asas probabilitas dan validitas eksternal untuk proses generalisasi dari analisis statistik induktif yang digunakan (Zainudin 1988: 92).

Variabel dalam penelitian ini terdiri dari variabel bebas yang pertama latihan medicine ball adalah Latihan pliometrik dengan cara berdiri dibelakang garis batas sambil memegang bola medicine dengan kedua tangan di atas kepala dengan posisi badan tegak. Kaki melangkah ke depan, kemudian bola didorong ke depan untuk dipantulkan ke dinding secepat dan sekuat mungkin dan menangkap kembali bola tersebut. Latihan ini dilakukan dengan beban $70 \%-80 \%, 2-3$ set dengan repetisi tiap setnya $8-15$ kali, durasi setiap set 30 detik, interval istirahat 2 menit antar set, selama 6 minggu dan frekuensi latihan 3- 4 kali seminggu. Variabel yang kedua adalah latihan clapping push up adalah latihan pliometrik dengan cara posisi badan tidur telungkup rata lantai bertumpu pada ujung kedua jari kaki dan telapak tangan, kedua siku ditekuk dan menempel disamping dada, pandangan mata normal. Kemudian luruskan kedua siku ke atas diikuti seluruh badan ikut terangkat ke atas dalam bentuk lurus satu garis diikuti gerakan tepukan kedua telapak tangan. Kemudian turunkan badan sampai dada menyentuh lantai, kembali ke sikap semula dan gerakan ini dihitung satu gerakan. Gerakan ini dilakukan berulang-ulang dengan repetisi 8 - 12 kali, 2-3 set, latihan dilakukan selama 6 minggu dan frekuensi latihan 3-4 kali seminggu. Variabel yang ketiga adalah daya ledak otot lengan yaitu Kemampuan otot lengan untuk mendorong bola medicine ke depan secepat dan sekuat mungkin sebanyak tiga kali lemparan, dengan cara posisi berdiri dibelakang garis batas, memegang bola medicine dengan kedua tangan di belakang kepala dengan posisi badan tegak dan lurus. Nilai yang diperoleh adalah jarak yang terjauh dari ketiga ulangan yang dilakukan (dalam satuan meter). Jarak diukur dari tempat jatuhnya bola hingga tempat dimana posisi subjek berdiri.

Tata cara pelaksanaan penelitian adalah Identifikasi dan perumusan masalah penelitian, menentukan subjek penelitian yang akan dilibatkan, melakukan pengukuran berat badan, tinggi badan dan indeks masa tubuh, selanjutnya subjek penelitian mengisi biodata dan informed consent, persipan intstrumen penelitian, pelaksanaan pre test daya ledak otot lengan dengan medicine ball test, subjek 
melakukan tes awal untuk menentukan dosis latihan, pelaksanaan latihan medicine ball dan clapping push up, pelaksanaan post test daya ledak otot lengan dengan medicine ball test dan yang terakhir adalah analisis data.

Instrumen yang dipergunakan dalam penelitian ini adalah meteran, stop watch dengan ketelitian 0,01 detik, Timbangan badan yang dilengkapi dengan pengukur tinggi badan, peluit, dinding tembok, medicine ball dengan berat $2,3 \mathrm{~kg}$, peralatan tulis menulis, kamera digital di gunakan untuk mendokumentasikan setiap kegiatan yang berkaitan dengan penelitian ini.
Data hasil penelitian selanjutnya diolah dengan uji statistik deskriptif, uji paired $t$ test, independent sample $t$ test dengan menggunakan program $\mathrm{R}$.

\section{HASIL DAN PEMBAHASAN}

\section{Hasil}

Analisis statistik deskriptif digunakan untuk memenuhi persyaratan pada uji normalitas yang digunakan untuk mengetahui pengaruh latihan medicine ball dan clapping push up terhadap daya ledak otot lengan.

Tabel 1. Rerata dan simpangan baku daya ledak otot lengan sebelum dan sesudah latihan

\begin{tabular}{lccc}
\hline \multicolumn{1}{c}{ Pasangan Variabel } & N & \multicolumn{2}{c}{ Rerata Hasil Pemeriksaan (Rerata \pm SD) } \\
\cline { 3 - 4 } & & $\begin{array}{c}\text { Latihan medicine ball } \\
\text { (K1) }\end{array}$ & $\begin{array}{c}\text { Latihan clapping push up } \\
\text { (K2) }\end{array}$ \\
\hline $\begin{array}{l}\text { Pre test } \text { daya ledak otot lengan } \\
\text { (meter) }\end{array}$ & 18 & $5,727 \pm 0,956$ & $5,155 \pm 1,137$ \\
$\begin{array}{l}\text { Post test } \text { daya ledak otot } \\
\text { lengan (meter) }\end{array}$ & 18 & $7,183 \pm 0,973$ & $5,944 \pm 1,121$ \\
\hline $\begin{array}{l}\text { Keterangan: N (Jumlah sampel), SD (Standar deviasi) } \\
\end{array}$
\end{tabular}

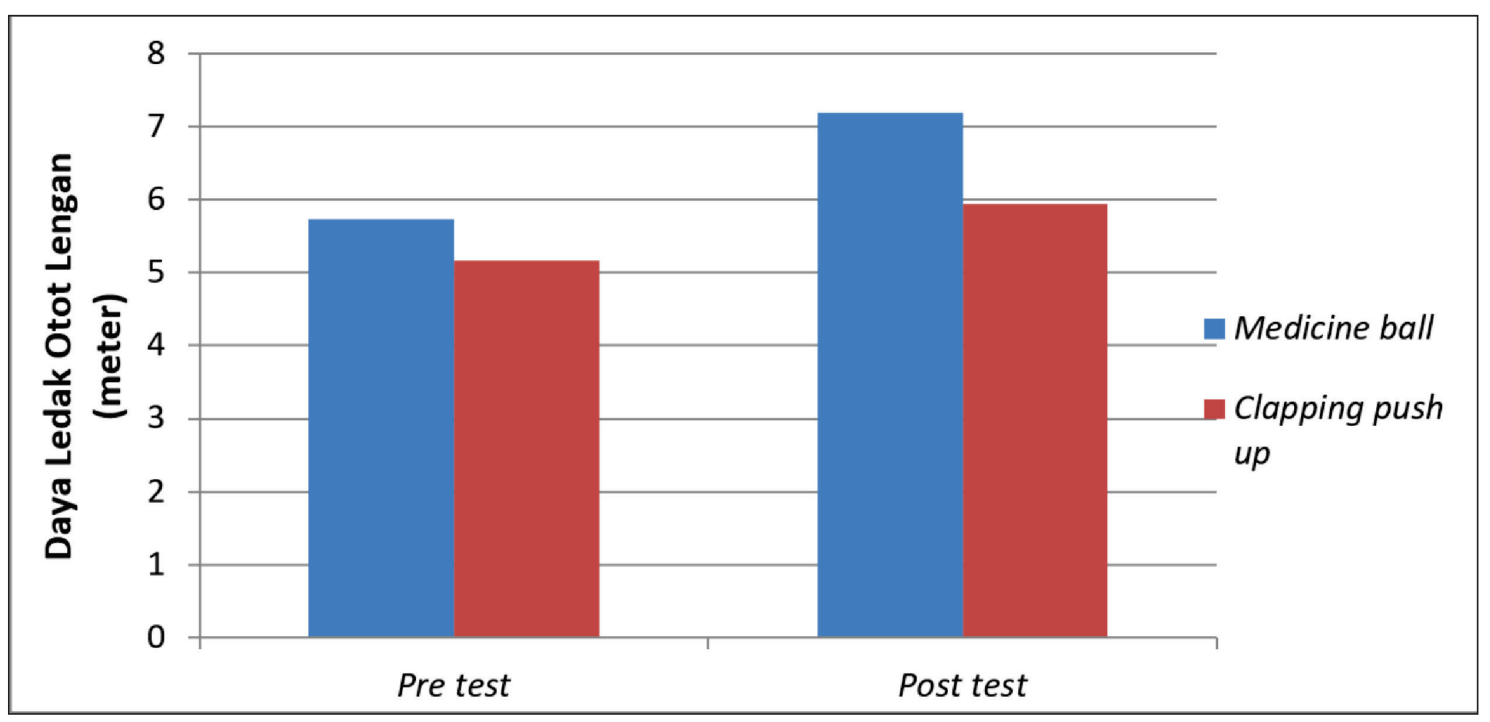

Gambar 1. Rerata daya ledak otot lengan sebelum dan sesudah perlakuan

Tabel 2. Hasil uji normalitas distribusi variabel daya ledak otot lengan pada kelompok medicine ball dan clapping push up

\begin{tabular}{cccc}
\hline \multirow{2}{*}{ Variabel } & Kelompok & Pre test & Post test \\
\cline { 3 - 4 } & Medicine ball (K1) & p & p \\
\hline $\begin{array}{c}\text { Daya Ledak Otot } \\
\text { Lengan (meter) }\end{array}$ & $\begin{array}{c}\text { Clapping push up } \\
\text { (K2) }\end{array}$ & $0,1992^{*}$ & $0,2411^{*}$ \\
\hline
\end{tabular}

Keterangan: $*=p>0,05$ menunjukkan data variabel berdistribusi normal 
Tabel 3. Pengaruh latihan pada variabel daya ledak (m) untuk masing-masing kelompok

\begin{tabular}{|c|c|c|c|c|c|c|c|c|c|}
\hline \multirow{2}{*}{ Kelompok } & \multirow{2}{*}{$\mathbf{N}$} & \multicolumn{2}{|c|}{ Pre test } & \multicolumn{2}{|c|}{ Post test } & \multirow{2}{*}{$\begin{array}{c}\text { Mean } \\
\text { Dif }\end{array}$} & \multirow{2}{*}{$\begin{array}{l}\text { SD } \\
\text { Dif }\end{array}$} & \multirow{2}{*}{$\mathbf{t}$} & \multirow[b]{2}{*}{ p } \\
\hline & & Mean & SD & Mean & SD & & & & \\
\hline $\begin{array}{c}\text { Medicine } \\
\text { ball }\end{array}$ & 18 & 5,727 & 0,956 & 7,183 & 0,973 & $-1,455$ & 0,465 & $-13,265$ & $0,00^{*}$ \\
\hline $\begin{array}{l}\text { Clapping } \\
\text { Push up }\end{array}$ & 18 & 5,155 & 1,137 & 5,944 & 1,121 & $-0,788$ & 0,227 & $-14,729$ & $0,00^{*}$ \\
\hline
\end{tabular}

Tabel 4. Hasil uji beda delta pada kelompok latihan medicine ball dan clapping push up

\begin{tabular}{|c|c|c|c|c|}
\hline \multirow{2}{*}{ Variabel } & \multirow{2}{*}{$\mathbf{N}$} & \multicolumn{2}{|c|}{$\begin{array}{c}\text { Rerata Hasil Pemeriksaan } \\
(\operatorname{Mean} \pm \mathrm{SD})\end{array}$} & \multirow{2}{*}{$\begin{array}{c}P \\
(\text { sig) }\end{array}$} \\
\hline & & Medicine ball & Clapping push up & \\
\hline $\begin{array}{l}\text { Delta daya ledak otot } \\
\text { lengan (meter) }\end{array}$ & 36 & $1,455 \pm 0,465$ & $0,788 \pm 0,227$ & 0,000 \\
\hline
\end{tabular}

\section{PEMBAHASAN}

\section{Latihan medicine ball dan clapping push up meningkatkan daya ledak otot lengan}

Hasil analisis Uji t berpasangan (pre-post test) pada variabel daya ledak membuktikan bahwa kelompok latihan medicine ball (K1) menunjukkan perbedaan yang sangat bermakna $(\mathrm{p}<0,05)$, kesimpulannya ada pengaruh yang signifikan terhadap daya ledak. Pada kelompok latihan clapping push up (K2) juga menunjukkan perbedaan yang sangat bermakna $(\mathrm{p}<0,05)$, kesimpulannya juga menunjukkan ada pengaruh yang signifikan terhadap daya ledak.

Maka hipotests yang menyatakan latihan medicine ball dan clapping push up meningkatkan daya ledak, diterima. Mekanisme terjadinya peningkatan tersebut diatas, terutama disebabkan oleh adaptasi persarafan yaitu terjadinya peningkatan persentase aktivasi motor unit, perubahan pada fungsi kontraktil otot yaitu peningkatan pada momen gaya kontraksi otot (twitch torque), dan hipertropi otot (meskipun terjadi sedikit) serta terjadinya peningkatan pada koordinasi ketrampilan motorik (Sallis dan Massimino, 1997: 506). Keuntungan secara umum pada metabolisme dan otot saraf akibat latihan adalah kecepatan konduksi saraf meningkat, masa otot meningkat, ATP / PC meningkat, glikogen otot meningkat, peningkatan sintesis protein untuk perkembangan otot (Zumerchi, 1997: 593).

\section{Perbedaan pengaruh antara latihan medicine ball dan clapping push up terhadap daya ledak remajausia 13 - 16 tahun}

Uji independet sample $t$ test terhadap perubahan variabel penelitian antar kelompok latihan menunjukkan bahwa ada perbedaan perubahan yang bermakna pada variabel daya ledak $(\mathrm{p}<0,05)$. Kesimpulan hasil ini menunjukkan arti bahwa latihan medicine ball dan clapping push up yang dilakukan baik pada K1 dan K2, menghasilkan perbedaan perubahan atau perbedaan peningkatan terhadap kemampuan daya ledak.

Hal ini memberi kesimpulan bahwa, walaupun latihan pliometrik medicine ball dan clapping push up sama-sama memperngaruhi perubahan atau peningkatan pada daya ledak, tetapi kedua model latihan pliometrik tersebut memiliki pengaruh yang berbeda terhadap perubahan atau peningkatan daya ledak, yaitu bahwa latihan pliometrik medicine ball lebih meningkatkan daya ledak dari pada latihan pliometrik clapping push up. 
Perbedaan pengaruh yang terjadi pada $\mathrm{K} 1$ dan K2 pada variabel daya ledak, kemungkinan akibat perbedaan gerakan. Perbedaan yang diamati tersebut adalah (1) bahwa pliometrik medicine ball, dalam pelaksanaannya lebih mudah dilakukan, sedangkan pliometrik clapping push up, pelaksanaannya sulit dilakukan akibat beban kerja yang lebih besar diakibatkan momentum jatuh pada trunk, (2) perbedaan waktu tempuh dari lemparan bola medicine dan tepukan kedua telapak tangan saat fase melayang pada latihan clapping push up.

Waktu tempuh latihan pliometrik medicine ball, tampaknya lebih cepat dari pada clapping push up, yang berimplikasi pada kecepatan gerakan yang lebih tinggi pada gerakan medicine ball, sedangkan kecepatan gerakan dengan usaha maksimal merupakan syarat penting untuk mencapai hasil latihan pliometrik yang optimal (Radcliffe dan Farentinos, 1985:21).

\section{KESIMPULAN}

Berdasarkan hasil penelitian dan hasil analisis data yang telah dilakukan, dapat diperoleh kesimpulan sebagai berikut:

1. Latihan medicine ball dapat meningkatkan daya ledak otot lengan pemain bulutangkis remaja usia 13 - 16 tahun.

2. Latihan clapping push up dapat meningkatkan daya ledak otot lengan pemain bulutangkis remaja usia $13-16$ tahun.

3. Latihan medicine ball lebih meningkatkan daya ledak otot lengan pemain bulutangkis remaja usia 13 - 16 tahun dibandingkan latihan clapping push up.

\section{DAFTAR PUSTAKA}

Alhusin, S., 2007. Gemar bermain bulutangkis, Surakarta: CV Seti-Aji

Astrand, P.D.,Rodahl, K, 1986. Textbook of work physiological basic of exercise. New York: Mc.Graw Hill Brooks Company

Bompa. 1983. Theory and methodology of training the key to athletic performance. Lowa Kendall/Hunt Publishing Company

Bompa. 1994. Theory and methodology of training: The Key to Athletic Performance.Third Edition, lowa: Kendall/Hunt Pub. Company, pp. 77-82.

Chu D. A., 1992. Jumping into plyometrics, chamign, Illionis: Leisure Press. Pp. 1, 20,90.

Feigenbaum A.D. dan Micheli L. J., 1996, 'Youth strength training', Current Comment from the ACSM, Indianapolis. Pp.62-72.

Fox EL, Bower RW and Foss ML, 1993. The physiological basis for exercise and sport. WM. C. Brown Communication, Ins., USA. Pp. 96-102, 136-160. 322-326.

Grice, Ton,. 1996. Badminton step to success. Human Kinetics Publisher, Inc

Guyton Ac, Hall JE, 1996. Textbook of medical physiology. Philadelphia : WB Sauders Company. Pp.73, 583, 685-691.

Harold M. Barrow, 1979. Practical approach to measurement in physical education, USA: Lea and Febiger

Harsono, 1988. Coaching dan aspek-aspek psikologi dalam coaching. Jakarta : Depdikbud Dirjen Dikti.

Harsono, 1993. Latihan kondisi fisik. Jakarta: Pusat Pendidikan dan Penataran (KONI PUSAT).

Hurlock E. B., 1985. Child development. 7nd ed. Singapore: McGraw-Hill Book Company. Pp. 118. 
Lesmana, I, S, 2012. Metode latihan beban dan daya tahan otot. Esa Unggul.

Ishak, M, 2011. 'Pengaruh latihan medicine ball terhadap kemampuan pukulan lob dalam permainan bulutangkis'. Jurnal, Nomor 1 Tahun 4, Februari 2012.

Setiawan, I., 1989. Teori belajar mengajar motorik. Jakarta: PIO KONI Pusat.

Jonson B.L., Nelson J.K., 1986. Practical measurements for evaluation in physical education, 4nd edition, New York: Macmillan Publishing Company, pp 228-229.

Kaluger G. Dan Kaluger M.F., 1984. Human development, the span of life. Third Edition. St. Louis, Missouri: Times Mirror/Mosby College Publishing. Pp. 4, 351.

Komi P. V., 1992. Strength and power in sport, The Encyclopedia of Sport Medicine an IOC Medical Commission Publication in collaboration with the International Federation of Sport Medicine, London: Blackwell Scientific Publications.

Kraemer J William and Fleck J.'Strength training for young athletes'. Pages 4-5.

Manuaba, I. B. A,1983. Aspek ergonomi dalam perencanaan komplek olahraga dan rekreasi. Naskah lengkap Panel Diskusi Rencana Induk Gelora Jakarta: 21 September 1983

Morrow J.R, 2006. Measurement and evaluation in human performance. Kanada: Human Kinetics.

Nossek, J, 1982. General teori of training, (Terjemahan M. Furqon H). Surakarta: Sebelas Maret University Perss.

Nurhasan, 1986. Tes dan pengukuran olahraga.Bandung : FPOK IKIP.

Pate RR, Mc. Cleghan B, 1984. Rotella R. Scientific foundation of coaching, Philadelphia: Sounders College Publishing, pp. 301-305.

PB. PBSI, 2001-2005. Pedoman praktis bermain bulutangkis terbaru.

Picone R.E., 1999. Strength training children, Fitness Management Magazine, Los Angeles, California, Vol. 15, No. 7: pp. 32-35. Accessed February 2015.

Poole James, 1982. Belajar bulutangkis. Bandung: Pioner Jaya.

Poole, J, 2009. Belajar bulutangkis. Bandung: Pioner Jaya.

Powers, S. K., Howley, E. T.2004. Exercise physiology, theory and application to fitness and performance. 5th Edition. New York: Mc. Graw Hill Companies.Inc.

Radcliffe J.C. dan Farentinos R.C, 1985. Plyometrics explosive power training. 2nd ed. Champaign, Illionis: Human Kinetics Published, Inc. Pp. 3, 30-83,111.

Sajoto, M, 1988. Pembinaan kondisi fisik dalam olahraga. Semarang : FPOK IKIP.

Sherwood L, 2001. Human physiology : From Cell to system, 2. Edisi International Thomson Publishing Inc.

Sudjana, 1992. Metode statistika, Penerbit Tarsito, Bandung: hal 299-307.

Suharno, HP, 1993. Ilmu kepelatihan olahraga. Yogyakarta.

Sugiarto, I, 2002. Total badminton. Solo: CV. Setyaki Eka Anugerah.

Sukadiyanto, 2005. Pengantar teori dan metodologi melatih fisik. Yogyakarta: FIK Universitas Negeri Yogyakarta.

Thibodeau dan Patton, 1992. Structure and function of the body. 9nd ed. St. Louis, Missouri: 
Mosby-Year Book, Inc. Pp. 108-111.

Tohar, 1992. Olahraga pilihan bulutangkis, Departemen Pendidikan \& Kebudayaan, Direktoral Jendral Pendidikan Tinggi: Jakarta: Proyek Pembinaan Tenaga Kependidikan.

Vossen, F, J, 2000. ' Comparison of dynamic push up training and plyometric push up training on upper body power and strength'. Human Kinetics. Canada. 14(3), 248-253.

Wilmore J.H., Costill DL., 1994. Physiology of sport and exercise. Human Kinetics. USA. Pp. 16-40, 68-74, 80-83, 416.

Zainudin, M., 2011. Metodologi penelitian. Surabaya: Universitas Airlangga Press. Pp. 53, 38$48,92$.

Zumerchik J., ed., 1997. Encyclopedia of sport science, Volume 2, New York: Mac Millan Inc. Pp. 16-17, 593, 716-717. 